\title{
Repairing Effects of Aqueous Extract of Kalanchoe pinnata (Lmk) Pers. on Lupus Nephritis Mice
}

\author{
Niken Indriyanti ${ }^{1 *}$, Afrillia Nuryanti Garmana ${ }^{2}$, Finna Setiawan ${ }^{3}$
}

\section{Niken Indriyanti ${ }^{*}$, Afrillia Nuryanti Garmana ${ }^{2}$, Finna Setiawan ${ }^{3}$}

'Department of Pharmacology, Faculty of Pharmacy, Mulawarman University, East Kalimantan, INDONESIA ${ }^{2}$ Department of Pharmacology and Clinical Pharmacy, School of Pharmacy, Bandung Institute of Technology, West Java, INDONESIA. ${ }^{3}$ Department of Pharmaceutical Biology, Faculty of Pharmacy, Universitas Surabaya, East Java, INDONESIA.

\section{Correspondence}

\section{Dr. Niken Indriyanti}

Faculty of Pharmacy, Department of Pharmacology, Mulawarman University, JIn. Panajam Kampus Gunung Kelua, Samarinda 75119 INDONESIA.

Phone and fax: +62 541739491

E-mail: niken@farmasi.unmul.ac.id

\section{History}

- Submission Date: 22-12-2017:

- Review completed: 10-02-2018;

- Accepted Date: 10-02-2018

\section{DOI : 10.5530/pj.2018.3.89}

\section{Article Available online}

http://www.phcogj.com/v10/i3

\section{Copyright}

(C) 2018 Phcog.Net. This is an openaccess article distributed under the terms of the Creative Commons Attribution 4.0 International license.

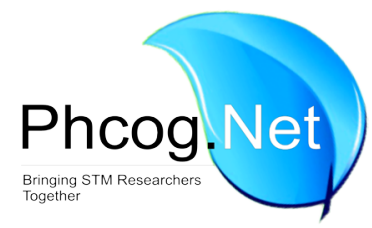

\begin{abstract}
Kalanchoe pinnata (Lmk) Pers (KP) has an immunosuppressive effect on delayed-type hypersensitivity test. Based on it, this research aimed to determine the repairing effects of aqueous extract of KP on lupus nephritis mice and identified its active compound. The KP extract profile was determined using UPLC-OTOF-MS/MS instrument. We examined six mice groups consisting of three curative treatment groups, one standard group receiving prednisone, one preventive group receiving KP extract, and one healthy (healthy and untreated) group. At the end of the experiment, we measured the proteinuria and renal histology parameters. To recognize the active compound in the KP profile, we performed in silico assays for the flavonoid compounds to bind to the glucocorticoid receptor. We played in silico tests for the flavonoid compounds to identify the active compound in the KP profile. We found the repairing effect of KP was detected in the kidney, demonstrated by its low proteinuria level and its better tissue structure. In the curative group, the urine protein level and its glomerular inflammation decreased. In the preventive group, the aqueous extract of KP could prevent lupus nephritis manifestations in the kidney. Bryophyllin A is the most active compound of the KP. However, further research is needed to understand the mechanism involved. We conclude, the aqueous extract, especially its bryophyllin A, have beneficial effects in repairing the function and tissue structure of lupus manifestations in mice kidney.

Key words: Lupus, Glomerulonephritis, Inflammation, Proteinuria, Docking.
\end{abstract}

\section{INTRODUCTION}

Natural treatment for lupus nephritis is a very potent and challenging on drug development. A large number of medicinal plants have beneficial effects which can be used in lupus nephritis treatment, such as immunosuppressant, antioxidant, anti-inflammatory, and antidepressant. These plants have not been explored

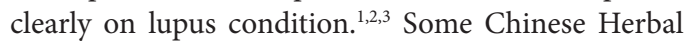
Medicine, Ayurveda, and Traditional Kampo treatment which were used for treating lupus have been studied for its efficacy. However, some of the traditional medicines have side effects on liver enzyme abnormality. ${ }^{4}$ Therefore, we investigated a lupus candidate drug from a medicinal plant which has a hepatoprotective activity, and also known as a nontoxic material, Kalanchoe pinnata (Lmk) Pers leaves (KP).

Polar compounds in aqueous extract of KP has beneficial effects for lupus condition. The activities include anticonvulsant, ${ }^{2}$ anti-nociceptive and anti-inflammatory, ${ }^{7,8}$ immunosuppressant, ${ }^{9,10}$ and $\mathrm{T}$ cell suppression. ${ }^{11}$ It also has a relaxant uterus effect so that it is safe for maternity. ${ }^{12,13}$ fenoterol, in human myometrium. KP is also a safe material proved by using an accurate acute and subchronic toxicity test. ${ }^{14}$ Compounds found KP are quercetin glycosyl conjugates, rutin, stigmasterol, 3,8-dimethoxy-4,5,7-trihydroxyflavone, friedelin, epigallocatechin-3-o-syringate, luteolin, kaempferol, quercetin, ${ }^{15,16}$ quercetin-3L-rhamnosido-L-arabino furanoside, quercetin-3-O-diarabinoside, kaempferol-3 glucoside, bryophollone, bryophyllin A, Bryophyllin C, bersaldegenin-3-acetate, bersaldegenin-1,3,5-orthoacetate, daigremontianin. ${ }^{17,18}$

KP has many beneficial effects and safety profiles, so it is appropriate to be developed as a new drug candidate for lupus nephritis. Therefore, this research determined the efficacy of the KP extract used in a lupus model. A well-known lupus model, Pristaneinduced lupus, was used based on its broad severe lupus nephritis manifestations. ${ }^{3,19,20}$ The efficacy of the KP comes from multiple compounds, but we can predict the active compounds on lupus responsible receptors, such as glucocorticoid. Moreover, this research focused on the effect of aqueous extract of $\mathrm{KP}$ on repairing the lupus nephritis manifestations and the potential active compounds involved.

\section{MATERIALS AND METHODS}

\section{MATERIALS}

The Kalanchoe pinnata (Lmk) Pers fresh leaves (KP) were collected from Manoko, Bandung. All of the leaves below the fourth top leaves were used. The plant identification was confirmed at the Herbarium Bandungense, Bandung Institute of Technology. 
Pristane which contains 2,6,10,14 tetramethylpentadecane (TMPD) $\geq 98 \%$ was purchased from Sigma-Aldrich.

Female Balb/c mice aged seven weeks were purchased from LPPT UGM. Mice were housed under specific conditions. They were fed by using standard diet and water ad-libitum. We also use reagent strips for urine analysis (Verify') to check the level total protein in the urine of each mouse tested.

\section{METHODS}

\section{Preparation of the extract}

Aqueous extract of KP leaves was processed from pressed fresh leaves. The extract was dried by using freeze dryer equipment (Eyela). The KP extract profile was measured by using UPLC-QTOF-MS/MS tandem instrument (Waters) by using Acquity UPLC column BEH C18 $1.7 \mu \mathrm{m}$ $2.1 \times 50 \mathrm{~mm}$, flow rate $0.3 \mathrm{ml} /$ minute. The injected volume was $5 \mu \mathrm{l}$ (the concentration of $5000 \mu \mathrm{g} / \mathrm{L}$ ). The temperature used was $40^{\circ} \mathrm{C}$. Also, the eluent used was A: $\mathrm{H} 2 \mathrm{O}+$ formic acid $0.1 \%$, B: acetonitrile + formic acid $0.1 \%$.

\section{Experimental grouping}

An animal model for lupus used was Pristane-treated mice. Female $\mathrm{Balb} / \mathrm{c}$ mice were injected by using $0.5 \mathrm{~mL}$ Pristane intraperitoneally, and then the booster injection was done at the day $90^{\text {th }} \cdot{ }^{10}$ Proteinuria level was measured at $5^{\text {th }}$ month after the induction and then lasted until the severe sign detected at month $8^{\text {th }}$. All of the induced mice experienced proteinuria at the level of $++(100 \mathrm{mg} / \mathrm{dL})$. The mice were grouped into some treatment groups ( $\mathrm{n}=8$ per group). Three treatment groups received the aqueous extract of $\mathrm{KP}$ at the doses of 200,400 , and $600 \mathrm{mg} / \mathrm{kg}$ body weight. There also positive control mice which received prednisone at a dose of $25 \mathrm{mg} / \mathrm{kg}$ body weight. The other groups were a preventive group that received extract at doses $200 \mathrm{mg} / \mathrm{kg}$ body weight and the standard group that did not induce by using Pristane.

\section{Treatment}

The KP extract was given orally to the treatment groups for 21 days. Protein level in the urine of all groups was measured every seven days. At the day $21^{\text {st }}$, mice were sacrificed then the renal histology observation was done by using Haematoxylin-Eosin (HE) staining. The data was analyzed by using Oneway ANOVA. This protocol was approved by the local ICUC of Faculty of Veterinary Medicine, Universitas Airlangga, Indonesia, with the number of 512-KE.

\section{Docking analysis to predict the potentially active compounds}

The in silico study was performed by using glucocorticoid receptor (GeneBank) and the chemical structures of some flavonoid compounds in KP, and also the prednisone chemical structure (PubChem). The structures were stabilized by using Chem3D Program, and then the docking was performed by using Molegro Virtual Docker. All of the programs used were licensed programs of Universitas Airlangga.

\section{RESULTS}

\section{Characteristics of the aqueous extract of Kalanchoe pinnata (Lmk) Pers (KP)}

The yield of the extract was $1.95 \% \mathrm{w} / \mathrm{w}$. Based on the organoleptic observation, the extract was dark yellow hygroscopic crystals resembling light materials. It was kept in the freezer until it was used. The identity profile of aqueous extract used was provided as a chromatogram profile (Figure 1) obtained using UPLC-QTOF-MS/MS tandem system.



Figure 1: The profile of chemical compounds in aqueous extract of Kalanchoe pinnata (Lmk) Pers. Leaves.

The main compound was at the retention time of 2.79 and was predicted as flavonoid compounds. A lot of literature mention the name of specific flavonoid compounds found in this plant. This data supported by a phytochemical screening data that show the presence of flavonoids, saponin, tannin, and steroid/triterpenoid. Besides, the physical characteristics of the KP extract including water content $9.00 \% \mathrm{v} / \mathrm{w}$, compounds soluble in water $54.34 \% \mathrm{w} / \mathrm{w}$, and compounds soluble in ethanol $3.57 \% \mathrm{w} / \mathrm{w}$. The characteristics exhibit beneficial and stable features of a solid material.

Three compounds in aqueous extract of KP has been widely studied. A lot of chemical compounds were found, such as steroids, terpenoids, flavonoids, phenolic, tannin, alkaloids, glycosides, carbohydrates, and proteins. The aqueous extract contains carbohydrates, proteins, flavonoids, phenolic, tannins, and glycosides. The leaves contain astragalin, 3,8-dimethoxy-4,5,7-trihydroxyflavone, friedelin, epigallocatechin-3-osyringate, luteolin, rutin, kaempferol, quercetin, quercetin-3L-rhamnosido-L-arabino furanoside, quercetin-3-O-diarabinoside, and kaempferol-3-glucoside. ${ }^{16,21}$ These multiple compounds might have the synergic effects that reduce lupus nephritis manifestations.

\section{The effects of aqueous extract of Kalanchoe pinnata (Lmk) Pers leaves on lupus nephritis mice}

The mice received a daily dose of aqueous extract of KP during 21 days. The protein level of the urine of the treated mice groups was decreased (Table 1). Proteinuria is a parameter for severity of nephritis. ${ }^{22,23}(-/-$ Moreover, there was no severe proteinuria obtained on the mice until the $6^{\text {th }}$ month after the induction. The mice only had mild proteinuria $+(30$ $\mathrm{mg} / \mathrm{dL}$ ) which revealed the low disease progress. This result was biased because the normal mice could reach proteinuria at the same level.

Then, the induction time was continued with a strict observation of proteinuria every seven days. As a result, the mice had proteinuria ++ $(100 \mathrm{mg} / \mathrm{dL})$ on the month $8^{\text {th }}$. Thus, they were ready for experimental grouping.

After the treatment period, the trend of proteinuria level decreased from level $++(100 \mathrm{mg} / \mathrm{dL})$ to level $+(30 \mathrm{mg} / \mathrm{dL})$ except the negative control groups. On the treatment groups, the dose of $200 \mathrm{mg} / \mathrm{kgBW}$ was the one that more active to decrease proteinuria level. The result was not as stable as the prednisone effect. On the preventive group, the proteinuria did not increase although they were injected twice using Pristane. Their physical condition showed a healthy behavior.

Proteinuria level was not the primary parameter to measure the severity of nephritis. Therefore, the observation was conducted in renal histology observation. Haematoxylin-Eosin (HE) staining showed the differences of each treatment effect on renal tissue structure. The results were in Figure 2.

The normal renal tissue of normal mice (Figure 2a) indicated by the mesangial area (long black arrow) seems thin with a regular structure, 
Table 1: Proteinuria Level Before And After Kp Extract Treatment.

\begin{tabular}{|c|c|c|}
\hline \multirow[t]{2}{*}{ Group } & \multicolumn{2}{|c|}{ Protein level in the urine $(\mathrm{mg} / \mathrm{dL})$} \\
\hline & Before treatment & After treatment \\
\hline Treatment group at a dose of $200 \mathrm{mg} / \mathrm{kg}$ BW KP & $200.00 \pm 115.47$ & $65.00 \pm 40.41^{*}$ \\
\hline Treatment group at a dose of $400 \mathrm{mg} / \mathrm{kg}$ BW KP & $65.00 \pm 40.41$ & $22.50 \pm 8.66^{*}$ \\
\hline Treatment group at a dose of $600 \mathrm{mg} / \mathrm{kg} \mathrm{BW} \mathrm{KP}$ & $112.00 \pm 110.77$ & $55.00 \pm 41.53^{\star}$ \\
\hline Prednisone at a dose of $25 \mathrm{mg} / \mathrm{kgBW}$ & $200.00 \pm 115.47$ & $30.00 \pm 0.00^{*}$ \\
\hline Negative control that received placebo & $82.50 \pm 35.00$ & $132.50 \pm 116.44$ \\
\hline Preventive group (treatment during induction time) & $15.00 \pm 0.00$ & $18.75 \pm 7.50^{*}$ \\
\hline
\end{tabular}

* Different significantly compared to the negative control group with $\mathrm{p}<0.05 . \mathrm{n}=8$ mice per group using t-test Statistics



$(\bullet)$

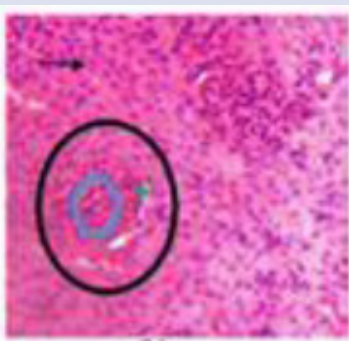

(b)
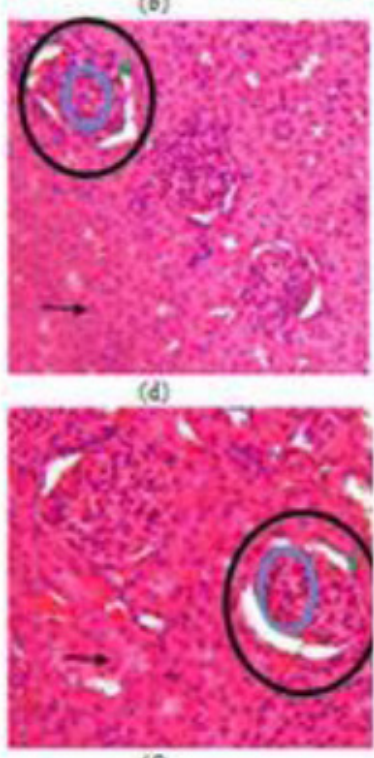

(f)

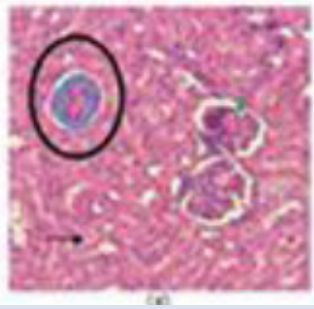

Figure 2 : Morphology of renal tissue at the magnitude of $400 \mathrm{x}$ by using light micrographs of a renal glomerulus of all groups Where; normal mouse of (a), negative control (b), treatment at the dose of $200 \mathrm{mg} / \mathrm{kg}$ BW (c), treatment at the dose of $400 \mathrm{mg} / \mathrm{kg} \mathrm{BW} \mathrm{(d),} \mathrm{treatment} \mathrm{at} \mathrm{the}$ dose of $600 \mathrm{mg} / \mathrm{kg}$ BW (e), prednisone at the dose of $25 \mathrm{mg} / \mathrm{kg} \mathrm{BW}$ (f), and preventive group (g). $\mathrm{n}=8$ mice per group.

and then the glomerulus (big circle) present between urinary spaces of Bowman's capsule. The glomerulus is a plaited mat of the capillary that has a filtration function. There is no proliferation of erythrocytes and inflammation cells inside the glomerulus (little circle). The area marked by green arrow is a position of glomerular basement membrane (GBM) that is thin in a healthy condition.

Furthermore, the positive control which only receiving placebo (Figure $2 \mathbf{b}$ ) had many structural changes, such as the GBM is thicker than usual with a proliferation of glomerulus results in inflammation. This condition has been reported before. ${ }^{10}$ Then, the glomerulus attaches the Bowman's capsule area, so the spaces are closed. In this situation, the filtration function performed difficultly. Besides, the mesangial area is thickened, are irregularly structured, and the cytoplasm cells are accumulated.

In the treatment group at the dose of $200 \mathrm{mg} / \mathrm{kgBW}$ (Figure 2c), the inflamed glomerulus was decreased. But, the GBM still looked thick. The cells accumulation is slightly reduced in the glomerulus. The mesangial area was shown the same structure with the Figure $\mathbf{2 b}$. On the other groups received the extract at the dose of 400 and $600 \mathrm{mg} / \mathrm{kgBW}$ (Figure 2 d and e), the anti-inflammatory effect still present. The urinary spaces in Bowman's capsule looked wider although not achieve the healthy appearance. The mesangial area looked more regularly structured by the increase of the dose. The GBM thickness seemed similar to the low treatment dose, but it needs further measurement.

On the standard group received prednisone (Figure $\mathbf{2 f}$ ), the accumulation of cells in the glomerulus and the glomerular inflammation were decreased although the GBM is still dense. The mesangial area looked thick, and not all of the area showed the repairing of the structure. At the last group, the preventive group, the histology structure is similar to the healthy mice.

The histology observation results show the repairing effect of aqueous extract of KP on many parts, such as tubules, glomerulus, GBM, and the Bowman's Capsule space. The treatment groups showed the alteration that it reduces the inflammation. The modification is not as good as the preventive group, but the effect is very potential to maintain the lupus patient stability.

Autoantigen-antibody complexes caused inflammation that occurred in glomerulus..$^{20,24}$ One of the autoantigens was nucleosome. Nucleosomes and anti-nucleosome antibodies have been shown to bind to the glomerular basal membrane (GBM). It is assumed that nucleosomes bind to the GBM via their histone proteins. The glomerulonephritis was developed by the formation of nucleosome-containing immune complexes. Also, there may be cross-reactivity of nucleosome-specific antibodies (e.g., with heparan sulfate or a so-far-unknown surface antigen) whereby these autoantibodies reach the glomeruli and cause inflammation. ${ }^{25,26}$ 
This result showed a capability of aqueous extract of KP in reducing the inflammation of glomerulus in the lupus nephritis mice model. It also prevents the mice from Pristane induction effect, so the mice keep normal although they received the second injection. The result showed a curative and preventive potency. But, further investigation needed to ensure this effect. These data indicate that aqueous extract of KP was useful to maintain immune system in lupus nephritis condition. This efficacy data is supported by the toxicity data reported by Ozolua ${ }^{14}$ stating that there was no toxicity occurred in acute and subchronic toxicity test. Because of the efficacy and the safety, aqueous extract of KP could be a good candidate for a natural treatment for lupus nephritis.

\section{The docking of some compounds in KP in glucocorticoid receptor}

The docking result did not show a correlation with cell culture test, the effect on the animal model or others. Docking did not calculate the bioavailability, toxicity, and other factors in the body. The main reason for the use of docking is to predict the compound which binds to a specific receptor (protein) well. We also could see how is the three dimensions geometric structure of a compound bound to the active site of the protein. In this research, we focused on three compounds found in KP, i.e., bryophyllin A, beta-sitosterol, and kaempferol-3-glucoside. The receptor was glucocorticoid receptor. This receptor has a very crucial role in immune homeostasis. The receptor is shown as a free water receptor. The ligand would be shed before the tested compound was inserted into the ligand space.

The compounds tested were prepared as 3D structures with an optimum geometric stability, using the Chem3D program. Then, the docking results are shown in Figure 3.

The ligand binding of bryophyllin A to glucocorticoid receptor presents through a hydrogen bond with amino acid residue Arg 611 (Figure 3). There is also a hydrophobic bonding with Gln 570, Leu 563, Met 560, Ile 747, Thr 739, Phe 749, Glu 748, Thr 561, Asn 564, and Phe 623. Figure $\mathbf{3 b}$ shows beta-sitosterol binds the receptor with hydrogen bonds to Arg


(c)

Figure 3: The Docking Result of Bryophyllin A (a), Beta-Sitosterol (b) and Kaempferol-3-glucoside (c) in the Glucocorticoid Receptor Tested Using Molegro Virtual Docker Program.
611 and Gln 570, and also hydrophobic bonds with Gln 738, Try 735, Phe 737, Leu 741, Thr 739. Ile 757, Phe 740, Cys 736, Met 601, Phe 749, Leu 753, Trp 600, Asn 564 and Leu 563. Fig. 5Sc showed that kaempferol3 -glucoside binds into glucocorticoid receptor using hydrogen bonds with Arg 611 and Asn 564, and hydrophobic bonds with Tyr 735, Leu 732, Cys 736, Phe 749, Met 639, Gln 642, Met 560, Met 646, Phe 623, Gln 570, and Met 604 .

According to the scoring calculation, the free binding energy of bryophylin A compound is $-66.6975 \mathrm{kcal} / \mathrm{mol}$, beta sitosterol is $-106.1340 \mathrm{kcal} / \mathrm{mol}$, and the kaempferol-3-glucoside is $-105.5710 \mathrm{kcal} / \mathrm{mol}$. The results show the lowest free binding energy was on bryophyllin A compound. This little power makes it easy to bind to the glucocorticoid receptor, so the anti-inflammatory effect occurs selectively. At last, the in silico prediction of the most active compound results in the bryophyllin A as the compound which has the lowest free binding energy in the glucocorticoid receptor. The experiment needs to be conducted using other receptors responsible for the lupus pathogenesis to support this result.

\section{DISCUSSION}

Aqueous extract of KP is sufficient to reduce inflammatory signs on kidney parameters of lupus nephritis mice. This anti-inflammatory effect reduces the high pro-inflammatory cytokines released when the glomerular inflamed due to the increasing number of immune complexes deposited inside. Flavonoid compounds in the KP have a high anti-inflammatory effect and also anti-oxidative results ${ }^{7,27,28,29}$ which support the regulation of immune responses. Lupus marked with irregular immune reactions which released suddenly if the triggering factors come. ${ }^{30,31}$ The KP treatment in all doses gives many beneficial outcomes in the kidney to reduce and inhibit the glomerular swelling. It followed by the lower proteinuria level. Both results show that the glomerulus moves to its normal condition.

The glomerulus disorder in lupus is different with the kidney failure signs, which cannot be repaired. Glomerulonephritis in lupus occurred as a result of complex immune deposit. ${ }^{32,33}$ It is possible for the immune complex to split and then eliminated from glomerulus, so the glomerulus function repaired.

In this research, all doses tested result in good outcomes to repair the kidney structure and function (Figure 2 and Table 1). It leads a further question regarding the active compound which responsible for the effect. According to the profile of the aqueous extract of KP, the primary compounds are flavonoid compounds. Therefore, we challenged some active compounds which potentially have an anti-inflammatory effect, i.e., bryophyllin A, beta-sitosterol, and kaempferol-3-glucoside. The compounds have good affinity to bind the glucocorticoid receptor, a receptor involved in the inflammatory process. The glucocorticoid receptor is a specific target for anti-inflammatory drugs. The compound which has the lowest binding energy to the glucocorticoid receptor was bryophyllin A (Figure 3). It means that bryophyllin A can efficiently bind the target site in glucocorticoid and results in the highest anti-inflammatory effect. However, the further research to calculate the concentration of bryophyllin $\mathrm{A}$ in the $\mathrm{KP}$ is necessary.

\section{CONCLUSION}

The aqueous extract of Kalanchoe pinnata (Lmk) Pers repairs on the kidney damage of Pristane-induced lupus nephritis mice. The potential flavonoid active compound which could be its active anti-inflammatory marker in this result is bryophyllin A.

\section{ABBREVIATIONS USED}

KP: Kalanchoe pinnata; TMPD: 2, 6, 10, 14-tetramethylpentadecane; GBM: glomerular basement membrane. 


\section{ACKNOWLEDGEMENT}

We thank Syamsi Dhuha Foundation for funding this research by Care For Lupus-SDF Awards Program, and we also appreciate Faculty of Pharmacy, Mulawarman University for the additional funds to complete the analysis.

\section{CONFLICT OF INTEREST}

The authors declare no conflict of interest.

\section{SUMMARY}

Drug development for advance safe lupus therapy is highly needed. The aqueous extract of Kalanchoe pinnata (Lmk) Pers (KP) fresh leaves has the activity to reduce lupus manifestation in the kidney of lupus mice. It reduces the glomerular inflammation, so the level of protein present in the urine can be decreased. Furthermore, the aqueous extract of KP has multiple compounds. The most potent compound of this material which can bind the glucocorticoid receptor efficiently is the structure of Bryoplyllin A, based on the in silico measurement.

\section{REFERENCES}

1. Yin $Y$, Gong $F Y, W u X X$, Sun $Y$, Li $Y H$, Chen $T$, et al. Anti-inflammatory and immunosuppressive effect of flavones isolated from Artemisia vestita. J Ethnopharmacol. 2008;120(1):1-6.

2. Cruz EA, Da-Silva SAG, Muzitano MF, Silva PMR, Costa SS, Rossi-Bergmann B. Immunomodulatory pretreatment with Kalanchoe pinnata extract and its quercitrin flavonoid effectively protects mice against fatal anaphylactic shock. Int Immunopharmacol. 2008:8(12):1616-21.

3. Aparicio-Soto M, Sánchez-Hidalgo M, Cárdeno A, Rosillo MÁ, Sánchez-Fidalgo S, Utrilla $\mathrm{J}$, et al. Dietary extra virgin olive oil attenuates kidney injury in pristaneinduced SLE model via activation of HO-1/Nrf-2 antioxidant pathway and suppression of JAK/STAT, NF-kB and MAPK activation. J Nutr Biochem. 2016;27:278-88

4. Palaniswamy R, Padma PR. Comparison of Three Herbal Plants for Best Free Radical Scavenging Activity. Int J Curr Pharm Res. 2017;9(3):9-11.

5. Biswas K, Chowdhury A, Das J, Hosen SMZ, Uddin R, Rahaman MS. Literature review on pharmacological potentials of Kalanchoe pinnata (Crassulaceae). African J Pharm Pharmacol. 2011:5(10):1258-62.

6. Aoki C, Hartati S, Santi MR, Lydwina, Firdaus R, Hanafi M, et al. Isolation and identification of substances with anti-hepatitis $C$ virus activities from Kalanchoe pinnata. Int J Pharm Pharm Sci. 2014;6(2):211-5.

7. Ferreira RT, Coutinho MAS, Malvar DDC, Costa EA, Florentino IF, Costa SS, et al. Mechanisms underlying the antinociceptive, anti-edematogenic, and antiinflammatory activity of the main flavonoid from Kalanchoe pinnata. Evidencebased Complement Altern Med. 2014;2014.

8. Julius Al, Charles A, Samuel NE, Ansong AD, Mahmood S, Samuel A, et al Nutraceutical with Anti-Inflammatory Activity for the Management of Airway Remodeling in Bronchial Asthma: Kalanchoe integra Var. Crenata (Andr.) Cuf Leaf Extract. Eur J Pharm Plants. 2014;5(3):250-61.

9. Bergmann RB, Costa SS, Borges MBS, da Silva SA, Noleto GR, Souza MLM, et al. Immunosuppressive effect of the aqueous extract of Kalanchoe pinnata in mice. Phytotherapy Res. 1994;8(7):399-402

10. Indriyanti N, Soeroso J, Khotib J. The immunosuppressant effect comparation between ethyl acetate and $n$-butanol fractions of Kalanchoe pinnata (Lmk) Pers in 2, 6, 10, 14-tetramethylpentadecane. J Trop Pharm Chem. 2017;4(1):7-13.

11. Coutinho MA, Muzitano MF, Cruz EA, Bergonzi MC, Kaiser CR, Tinoco LW, et al. Flowers from Kalanchoe pinnata are a rich source of T cell-suppressive flavonoids. Nat Prod Commun. 2012;7(2):175-8.

12. Hosomi JK, Ghelman R, Quintino MP, de Souza E, Nakamura MU, Moron AF Effects of chronic Bryophyllum pinnatum administration on Wistar rat pregnancy, Forschende Komplementarmedizin. 2014;21(3):184-9.

13. Gwehenberger B, Rist L, Huch R, Von Mandach U. Effect of Bryophyllum pinnatum versus fenoterol on uterine contractility. Eur J Obstet Gynecol Reprod Biol. 2004;113(2):164-71.

14. Ozolua RI, Idogun SE, Tamafel GE. Acute and Sub-Acute Toxicological Assess ment of Aqueous Leaf Extract of Bryophyllum pinnatum (Lam.) in SpragueDawley Rats. Am J Pharm Tox. 2010:5(3):145-51.

15. Nascimento LBDS, Leal-Costa MV, Menezes EA, Lopes VR, Muzitano MF, Costa SS, et al. Ultraviolet-B radiation effects on phenolic profile and flavonoid content of Kalanchoe pinnata. J Photochem Photobiol B Biol. 2015;148:73-81.

16. Sharker SM, Hossain MK, Haque MR, Chowdhury AA, Kaisar A, Hasan CM, et al. Chemical and biological studies of Kalanchoe pinnata (Lam.) growing in Bangladesh. Asian Pac J Trop Biomed. 2012;2(3):6-11.

17. Mahata S, Maru S, Shukla S, Pandey A, Mugesh G, Das BC, et al. Anticancer property of Bryophyllum pinnata (Lam.) Oken. leaf on human cervical cancer cells. BMC Complement Altern Med. 2012;12(1):15.

18. Maharani R, Fajriah S, Hardiawan R, Supratman U. Insecticidal bufadienolides from the leaves of Kalanchoe daigremontiana (Crassulaceae). Proceeding Int Semin Chem. 2008;(10):236-9.

19. Lin $Y$, Yan $Y$, Zhang H, Chen $Y$, He Y, Wang $S$, et al. Salvianolic acid A alleviates renal injury in systemic lupus erythematosus induced by Pristane in BALB/C mice. Acta Pharm Sin B. 2016:7(2):159-66.

20. Gardet A, Chou WC, Reynolds TL, Velez DB, Fu K, Czerkowicz M, et al. PristaneAccelerated Autoimmune Disease in (SWR X NZB) F1 Mice Leads to Prominent Tubulointerstitial Inflammation and Human Lupus Nephritis-Like Fibrosis. PLoS One. 2016;11(10):1-19

21. Milad R, El-ahmady S, Singab AN. Genus Kalanchoe (Crassulaceae): A Review of Its Ethnomedicinal, Botanical, Chemical and Pharmacological Properties. Pharmacol and Pharm. 2014;4(1):86-104

22. Urbonaviciute V, Starke C, Pirschel W, Pohle S, Frey S, Daniel C, et al. Toll-like receptor 2 is required for autoantibody production and development of renal disease in Pristane-induced lupus. Arthritis Rheum. 2013;65(6):1612-23.

23. Haridasan S, Sharma A, Rathi M. Treatment of membranous lupus nephritis Clin Queries Nephrol. 2014;3(2-4):106-13.

24. Yung S, Chan TM. Anti-dsDNA antibodies and resident renal cells: Their putative roles in pathogenesis of renal lesions in lupus nephritis. Clin Immunol. 2016;1-11.

25. Bruns A, Bläss S, Hausdorf G, Burmester GR, Hiepe F. Nucleosomes are major $T$ and $B$ cell autoantigens in systemic lupus erythematosus. Arthritis Rheum. 2000:43(10):2307-15.

26. Gatto M, laccarino L, Ghirardello A, Punzi L, Doria A. Clinical and pathologic considerations of the qualitative and quantitative aspects of lupus nephritogenic autoantibodies: A comprehensive review. J Autoimmun. 2016;69:1-1.

27. El Abdellaoui S, Destandau E, Toribio A, Elfakir C, Lafosse M, Renimel I, et al. Bioactive molecules in Kalanchoe pinnata leaves: Extraction, purification, and identification. Anal Bioanal Chem. 2010;398(3):1329-38.

28. Sharma $A$, Bhot $M$, Chandra N. in vitro antibacterial and antioxidant activity of Bryophyllum pinnatum (Lam.) Kurz. Int J Pharm Pharm Sci. 2014;6(1):558-60.

29. Nielsen CT, Rasmussen NS, Heegaard NHH, Jacobsen S. "Kill" the messenger: Targeting of cell-derived microparticles in lupus nephritis. Autoimmun Rev. 2016;15(7):719-25

30. Li X, Yue Y, Zhu Y, Xiong S. Extracellular, but not intracellular HMGB1, facilitates self-DNA induced macrophage activation via promoting DNA accumulation in endosomes and contributes to the pathogenesis of lupus nephritis. Mol Immunol. 2015;65(1):177-88.

31. Bonanni A, Vaglio A, Bruschi M, Sinico RA, Cavagna L, Moroni G, et al. Multiantibody composition in lupus nephritis: Isotype and antigen specificity make the difference. Autoimmun Rev. 2015;14(8):692-702.

32. Koga T, Ichinose K, Tsokos GC. T cells and IL-17 in lupus nephritis. Clin Immunol. 2016;1(2015):2-6.

33. Young DC.Computational drug design. Canada: John Wiley and Sons. 2009.

Dr. Niken Indriyanti: Is a lecturer in Department of Pharmacology, Faculty of Pharmacy, Mulawarman University, East Kalimantan Province, Indonesia. Her researches are about natural products for lupus.

Dr. Afrillia Nuryanti Garmana: Is a lecturer in Department of Pharmacology and Clinical Pharmacy, School of Pharmacy, Bandung Institute of Technology, West Java, Indonesia. She interests in pharmacological activity of natural and synthetic compounds.

Dr. Finna Setiawan: Is a lecturer in Department of Biology Pharmacy, Surabaya University, East Java, Indonesia. She focuses on natural compounds and its activities which are useful for drug discovery.

Cite this article: Indriyanti N, Garmana AN, Setiawan F. Repairing Effects of Aqueous Extract of Kalanchoe pinnata (Lmk) Pers. on Lupus Nephritis Mice. Pharmacog J. 2018;10(3):548-52. 